\title{
O Frasco Quebrado: desafios para a Bibliografia no mundo contemporâneo
}

The broken bottle: challenges for Bibliography in the contemporary world

\begin{abstract}
Marco Antônio de Almeida
Doutor em Ciências Sociais pela Universidade Estadual de Campinas - UNICAMP. Professor do Curso de Biblioteconomia e Ciência da Informação da Faculdade de Filosofia, Ciências e Letras de Ribeirão Preto da Universidade de São Paulo - FFCLRP/USP.

E-mail: marcoaa@ffclrp.usp.br
\end{abstract}

McKENZIE, Donald Francis. Bibliografia e a sociologia dos textos. São Paulo: EDUSP, 2018 .

No livro que compila suas conferências na British Library, D. F. McKenzie aborda o campo da bibliografia, contrapondo ao seu escopo tradicional uma visão mais ampla, voltada para as mutações contemporâneas dos textos. Para ele, a aceleração dos processos históricos pelos quais os textos mudam sua forma e conteúdo teriam tornado praticamente impossível a definição e a localização textual ao velho estilo.

A obra estrutura-se em duas partes. A primeira, dividida em três capítulos, reúne a transcrição das conferências realizadas pelo autor. $O$ conjunto propõe analisar o desenvolvimento da bibliografia histórica como campo de estudo, e como as mudanças da contemporaneidade a afetam. Em suas próprias palavras, a aceitação da bibliografia histórica no atual momento “... sinaliza uma mudança, parcial mas significativa, de questões de autoridade de texto para aquelas de disseminação e leitura enquanto questões de razão política e econômica." (p. 11). Nesse sentido, os capítulos acompanham a consolidação do livro como forma expressiva, passando pela migração dos textos para outros formatos, proporcionada pelas revoluções advindas nas mudanças tecnológicas no campo da comunicação, concluindo com considerações acerca das características da dialética da bibliografia na atualidade.

Na primeira conferência, "O livro como uma forma expressiva", a materialidade do livro é discutida num sentido diferente dos paradigmas tradicionais da bibliografia (voltados fundamentalmente para a descrição e catalogação dos impressos), centrando-se em seu potencial discursivo. Embora valorize a bibliografia física - "o estudo de signos que constituem textos e os materiais nos quais eles são registrados" - como um ponto de partida importante, considera-a, entretanto, como incapaz de definir a disciplina, visto que "não tem os meios 
adequados para representar os processos, as dinâmicas técnicas e sociais de transmissão e recepção de um leitor ou de todo um mercado deles." (p. 29). Desse modo, uma "sociologia dos textos" contrastaria com uma bibliografia mais ortodoxa, confinada à inferência lógica estabelecida a partir de signos impressos como marcas meramente arbitrárias.

Em "O frasco quebrado: textos fora dos livros", título da segunda conferência, McKenzie propõe uma ampliação do conceito de textualidade e de materialidade da escrita para uma multiplicidade de suportes, ao mesmo tempo em que questiona a ideia de livro (e, consequentemente, de escrita) como portador ou instrumento da verdade. Ele destaca a dificuldade de estabelecer o princípio bibliográfico em formas que não são livros, propondo uma abordagem mais pragmática e indicativa, buscando paralelismos em registros que possuem uma função textual, sujeitos a algum tipo de "controle bibliográfico", envolvendo interpretação e análise histórica. Dentro deste propósito, seria mais útil "pensar simplesmente em termos de homologias, de estruturas correspondentes, sugerindo que, qualquer que seja nosso campo específico - livros, mapas, impressos, tradições orais, teatro, filmes, televisão ou databases de computador - notamos certas questões comuns.” (p. 59) A partir desse pressuposto, McKenzie traça interessantes considerações e paralelismos com textos dispostos nessas linguagens e suportes tão distintos, passeando pelos mitos aborígenes, mapas ferroviários e climáticos, peças teatrais e adaptações de Shakespeare para os quadrinhos, dialogando com autores como Roland Barthes ou Christian Metz.

Finalmente, na terceira palestra, intitulada "A dialética da bibliografia atual", o autor retoma a distinção entre os dois conceitos de texto expostos nas palestras precedentes: um, sancionado pelo autor, controlável e definível historicamente, e outro, incompleto, instável, passível de mudanças por seus leitores, intérpretes ou públicos (embora não haja referências, é perceptível uma notável semelhança com o conceito de "obra aberta" de Umberto Eco). McKenzie enfatiza e aprofunda a discussão entre forma e conteúdo, buscando refletir acerca de novos caminhos para que os objetos da escrita possam ser pensados de forma mais ampla. Nesse sentido, ele propõe um conjunto de observações sobre a natureza da bibliografia e sua relação com os textos, concluindo que o desafio para os bibliógrafos - definir seus modos de uso, sua estrutura de ordenação e os futuros estudos que poderiam demandar - estava além do que o campo poderia oferecer naquele momento (1985). Em suas próprias palavras, "o que precisamos é nada menos do que um novo conceito do texto na história”. (p. 103) 
A segunda parte da obra corresponde ao ensaio intitulado "A sociologia de um texto: cultura oral, alfabetização e impressão na Nova Zelândia”. Trata-se de um trabalho caracteristicamente interdisciplinar, que parte de um problema clássico da bibliografia - o estabelecimento da autoridade textual - e que incorpora perspectivas históricas e antropológicas para ampliar e problematizar as questões envolvidas. Focando a Nova Zelândia no período situado entre meados de 1830 e meados de 1860, McKenzie reconstrói o movimento que vai da oralidade à introdução da impressão (passando pela escrita manuscrita), um processo que replica num contexto específico e quantificável a mesma revolução ocorrida na Europa sob a égide de Gutemberg. O foco de suas reflexões é um importante documento histórico, o Tratado de Waitangi, celebrado entre a Coroa Inglesa e os chefes maoris sobre a posse da terra. $\mathrm{O}$ tratado funciona como caso exemplar da oposição entre uma concepção eurocêntrica acerca do poder e do status das declarações escritas, de "documentos" materialmente estabilizados, e as concepções e acomodações mais flexíveis do consenso oral. O ensaio desenvolve e aprofunda algumas das questões abordadas pelo autor em suas conferências (com especial ênfase para a segunda). Em certa medida, também envereda por questões muito semelhantes àquelas desenvolvidas por seu contemporâneo Jack Goody, antropólogo inglês notabilizado por seus estudos acerca das relações entre cultura oral e cultura escrita ${ }^{1}$, mas que não é mencionado no livro.

Bibliografia e a sociologia dos textos levanta pelo menos dois pontos com os quais o campo da Ciência da Informação deveria dialogar. O primeiro diz respeito à compreensão da bibliografia como uma sociologia dos textos - ou seja, como uma área científica voltada à análise histórica dos processos sociais de produção, circulação e recepção dos textos. O segundo ponto, decorrente do anterior, debruça-se sobre os desafios que se colocam à bibliografia ao interrogar-se acerca dos textos que transcendem ao suporte tradicional do livro. Estes dois pontos levantam questões particularmente relevantes no momento atual, marcado tanto pela presença cada vez maior das tecnologias de comunicação e informação no cotidiano dos indivíduos, grupos e instituições como pela multiplicação exponencial de textos nos mais diversos suportes, proporcionada pelos processos de digitalização. Decorrem daí tanto questões de ordem teórico-conceitual - como a própria definição do conceito de texto, discussão interdisciplinar por natureza - como questões de ordem metodológica e até instrumental, envolvendo as especificidades técnicas e de linguagem relativas aos novos meios e suportes.

\footnotetext{
${ }^{1}$ GOODY, Jack. A domesticação da mente selvagem. Petrópolis: Vozes, 2012 (publicado originalmente em inglês em 1977).
} 
Estes desafios e perspectivas vislumbrados por McKenzie, decorridas três décadas de cibercultura desde que ele ministrou suas conferências, permanecem profundamente atuais.

Reler a obra de McKenzie hoje abre a perspectiva de pontes com diversas áreas de pesquisa e problematização. A título de exercício hipotético, sugerimos duas possibilidades de diálogos interdisciplinares. O primeiro seria com a concepção de representação social, tal qual sinteticamente exposta por Stuart Hall - o processo pelo qual os membros de uma cultura usam a linguagem para produzir sentido e conhecimento. Hall propõe uma abordagem construtivista que se apoia em duas vertentes: uma vertente semiótica/semiológica, influenciada por Saussure e Barthes, concentrada na maneira pela qual os signos produzem sentidos; uma vertente discursiva, influenciada por Foucault, que se concentra em como o discurso e as práticas discursivas produzem conhecimentos. As considerações acerca das concepções de texto propostas por McKenzie encontrariam aqui um terreno fértil para desdobrarem-se e aprofundarem-se. Um segundo diálogo possível poderia estabelecer-se a partir do conceito de "cultura da convergência", de Henry Jenkins, que permite focar particularmente as conexões entre os processos que caracterizam essa cultura e os processos tecnologicamente mediados de apropriação social do conhecimento e da informação. São perspectivas que, embora formuladas em âmbitos muito distintos, retomam as discussões mais amplas sobre identidades sociais e culturais, bem como os processos de produção, circulação e apropriação dos textos, temas tão caros a McKenzie. Isto só reforça a atualidade da discussão que ele propôs, ao levantar um conjunto de coordenadas teóricas e temáticas para contribuir com a atualização e ampliação do escopo do campo de pertinência da bibliografia perante os desafios culturais da contemporaneidade. 